\title{
New data on helminth fauna of birds of prey (Falconiformes, Accipitriformes, Strigiformes) in the Slovak Republic
}

\author{
P. KOMOROVÁ1* J. SITKO ${ }^{2}$, M. ŠPAKULOVÁ ${ }^{3}, Z$ Z. HURNÍKOVÁ ${ }^{3,1}$, R. SALAMATIN ${ }^{4,5}$, G. CHOVANCOVÁ ${ }^{6}$
}

\begin{abstract}
${ }^{1}$ Department of Epizootology and Parasitology, Institute of Parasitology, The University of Veterinary Medicine and Pharmacy in Košice, Komenského 73, 04181 Košice, Slovak Republic, ${ }^{*}$ E-mail: Petronela.Komorova@uvlf.sk; ${ }^{2}$ Ornitological Station of Commenius Museum in Přerov, Bezručova 10, 75002 Přerov, Czech Republic; ${ }^{3}$ Institute of Parasitology, Slovak Academy of Sciences, Hlinkova 3, 04001 Košice, Slovak Republic; ${ }^{4}$ Department of General Biology and Parasitology, Medical University of Warsaw, Chałubińskiego 5, 02-004 Warsaw, Poland; ${ }^{5}$ Department of Parasitology, National Institute of Public Health - National Institute of Hygiene, Chocimska 24, 00-719 Warsaw, Poland; ${ }^{6}$ Research Station and Museum of the Tatra National Park, 05960 Tatranská Lomnica, Slovak Republic
\end{abstract}

\section{Article info}

Received December 1, 2016 Accepted July 4, 2017

\begin{abstract}
Summary
In the years 2012-2014, carcasses of 286 birds of prey from the territory of Slovakia were examined for the presence of helminth parasites. The number of bird species in the study was 23 ; five belonging to the Falconiformes order, eleven to Accipitriformes, and seven to Strigiformes. A finding of Cestoda class comprehended 4 families: Paruterinidae (4), Dilepididae (2), Mesocestoididae (2) and Anoplocephalidae (1). Birds of prey were infected with 6 families Nematoda species of the Secernentea class: Syngamidae (1), Habronematidae (2), Tetrameridae (3), Physalopteridae (1), Acuariidae (1), and Anisakidae (2). Out of the Adenophorea class, the Capillariidae family (1) was confirmed. The Acanthocephala group was represented by the Paleacanthocephala class, the Centrorhynchidae family (3). Out of the Trematoda class, 12 different species of flukes were found, belonging to the Diplostomidae (5), Cyathocotylidae (1), Strigeidae (4), Opistorchidae (1), and Plagiorchidae (1) families. The most frequent helminth species infecting diurnal birds of prey was Strigea falconis. This fluke was confirmed in one bird species from the Falconiformes order and in eight species from the Accipitriformes order. In nocturnal birds of prey, the most common finding was the acanthocephalan Centrorhynchus aluconis, identified in four different host species of the Strigiformes order. In total, 23 helminth species were recorded for the first time in Slovakia.
\end{abstract}

Keywords: helminth parasites; infection; nocturnal and diurnal birds of prey

\section{Introduction}

Birds of prey are predatory animals residing at the top of a food chain and they usually get infected with parasites via ingestion of prey, thus serving as intermediate hosts of many parasite species. Types and diversity of the prey preferred by individual species represent one of the factors affecting the parasite diversity in those hosts.

Since majority of birds of prey species in Europe are protected, the research and knowledge of the parasite fauna is only fragmentary. Comprehensive research projects studying all helminth groups in birds of prey were accomplished by the Borgsteede et al. (2003),
Sanmartín et al. (2004), Illescas Gomez et al. (1993), and Santoro et al. (2012a, b).

Forty-three different species of birds of prey, belonging to the Falconiformes, Accipitriformes, and Strigiformes orders, nest or occur in Slovakia territory (Kovalik et al., 2010). The most abundant species is the common buzzard (Buteo buteo) that nests in different forest biotopes, but it is very well adapted also to the agricultural land. However in low quantities, on the territory of Slovakia we can also find the species that are very sensitive to the environmental changes associated with anthropogenic impacts (Circus pygargus, Milvus milvus) (Krivjanský, 2009).

In Slovakia, only two research papers, aimed at parasites in birds

\footnotetext{
$\bar{*}$ - corresponding author
} 
of prey, have been published in the $20^{\text {th }}$ century. Tenora \& Lusk (1960) and Škarda (1964) studied the helminth fauna of birds in Czechoslovakia and published several findings in birds of prey from the Slovak part of the country. For a subsequent period of 50 years, at the times of dynamic climate changes, no comprehensive research of this host group has been carried out. Recently, two papers on flukes and thorny-headed worms were published (Komorová et al., 2015; Komorová et al., 2016).

The aim of our study was to obtain the complex knowledge about the current status of the parasite fauna in birds of prey in Slovakia.

\section{Material and Methods}

During the period of $2012-2014,286$ carcasses of birds of prey belonging to 23 species of the Falconiformes, Accipitriformes, and Strigiformes orders were examined for the presence of helminths (Table 1). The research was conducted upon the permission issued by the Ministry of Environment of the Slovak Republic No. 6467/2012-2.26467/2012-2.2. The samples were collected from various locations of Slovakia in cooperation with departments of the State Nature Conservancy of the Slovak Republic - The Slovenský Kras National Park, The Slovenský Raj National Park, The Pieniny National Park, The Regional Conservation Centre in Prešov, and The Vihorlat Protected Area, as well as with the Museum of the Tatra National Park, the Clinic for Birds and Exotic Animals at the University of Veterinary Medicine and Pharmacy in Košice, The Raptor Protection of Slovakia, The Rehabilitation Station in The ZOO Bojnice, and The Košice Airport. Collected bird carcasses were frozen and subjected to helminthological necropsy. After de-freezing, all organ systems and body cavities were examined for the presence of parasites. Collected helminths were washed in distilled water and preserved in $70 \%$ ethanol. For morphological identification, the species belonging to the Trematoda and Cestoda classes were stained with iron acetocarmine (Georgiev et al, 1986). Lightening of specimens from the Adenopohorea, Secernentea, and Paleacanthocephala classes was carried out using glycerine or lactophenol. The species identification was conducted according to Dubois (1968, 1970), Gibson et al. (2002), Sitko (1998, 2001), and Bray et al. (2008) for Trematoda; Joyeux \& Timon-David (1934), Joyeux \& Baer (1936), Rausch (1948), and Khalil et al. (1994) for Cestoda; Hartwich (1975), Baruš et al. (1978), and Gibbons (2010) for Adenophorea; and Secernentea and Meyer (1933), Petrochenko (1958), Dimitrova et al. (1997), and Dimitrova \& Gibson (2005) for Paleacanthocephala. Ecological parameters (prevalence, mean intensity, diversity) were evaluated according to Bush et al. (2007).

The voucher specimens are deposited in the collection of The Institute of Parasitology at the SAS in Košice.

\section{Results}

Out of 286 examined birds, 156 (54.5\%) were infected with hel- minths, 17 out of 85 diurnal birds of prey from the Falconiformes order were infected (20\%), and the parasitic infection was confirmed in 114 out of 156 birds from the Accipitriformes order (73.1\%). In nocturnal birds of prey (Strigiformes order), helminths were found in 28 out of 45 individuals (62.2\%).

A total of 33 helminth taxa were registered. In the Falconiformes order, 9 different helminth taxa were determined - 2 Trematoda, 1 Cestoda, 4 Secernentea, and 1 Paleacanthocephala. In birds from the Accipitriformes order, in total 27 helminth species were found - 9 Trematoda, 6 Cestoda, 1 Adenophorea, 8 Secernentea, and 3 Paleacanthocephala. In nocturnal birds of prey (Strigiformes) 10 helminth species were detected - 2 Trematoda, 2 Cestoda, 1 Adenophorea, 4 Secernentea, and 1 Paleacanthocephala (Table 1). The information on parasite species, names and numbers of infected hosts $(\mathrm{NIH})$, prevalence (P in \%), intensity of infection (II), mean intensity (MI), and site of infection is summarized below.

\section{Platyhelminthes}

Trematoda

Diplostomidae Poirier, 1886

Conodiplostomum perlatum (Ciurea, 1911)

Host: $H$. albicilla ( $\mathrm{NIH}=1 ; \mathrm{P}=100 \%$; II=43) - first record in Slovakia

Site of infection: small intestine

\section{Conodiplostomum spathula (Creplin, 1829)}

Host: $A$. heliaca ( $\mathrm{NIH}=1 ; \mathrm{P}=16.7 \%$; $\|=13$ ) - first record in Slovakia Site of infection: small intestine

\section{Neodiplostomum attenuatum (Linstow, 1906)}

Host: $B$. buteo $(\mathrm{NIH}=29 ; \mathrm{P}=24.4 \% ; \|=1-224 ; \mathrm{Ml}=25)$, B. lagopus $(\mathrm{NIH}=1 ; \mathrm{P}=20 \% ; \quad \|=70), B$. rufinus $(\mathrm{NIH}=2 ; \mathrm{P}=50 \% ; \|=6-10$; $\mathrm{Ml}=8), P$. apivorus $(\mathrm{NIH}=1 ; \mathrm{P}=100 \% ; \|=3)$ - first records in Slovakia

Site of infection: small intestine

\section{Neodiplostomum canaliculatum (Nicoll, 1914)}

Host: $B$. bubo $(\mathrm{NIH}=1 ; \mathrm{P}=50 \% ; \|=1), \quad$. uralensis $(\mathrm{NIH}=5$; $\mathrm{P}=33.3 \%$; II=5-23; $\mathrm{Ml}=14$ ) - first records in Slovakia

Site of infection: small intestine

\section{Neodiplostomum spathoides Dubois, 1937}

Host: $B$. rufinus ( $\mathrm{NIH}=1 ; \mathrm{P}=25 \%$; $\|=4)$, C. aeruginosus $(\mathrm{NIH}=2$; $P=50 \% ; \|=8-15 ; M l=11.5)$ - first records in Slovakia

Site of infection: small intestine

Cyathocotylidae Mühling, 1898

Paracoenogonimus ovatus Katsurada, 1914

Host: $H$. albicilla ( $\mathrm{NIH}=1 ; \mathrm{P}=100 \% ; \|=1)$ - first record in Slovakia Site of infection: small intestine

Strigeidae Railiet, 1919

Parastrigea flexilis (Dubois, 1934) 


\begin{tabular}{|c|c|c|c|c|c|c|}
\hline \multirow[t]{2}{*}{ Order/bird species } & \multirow[b]{2}{*}{$\begin{array}{l}\text { No. of examined/ } \\
\text { parasitized birds }\end{array}$} & \multicolumn{5}{|c|}{ No. of birds parasitized by: } \\
\hline & & 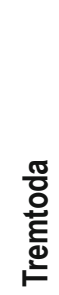 & 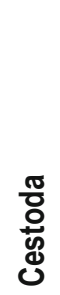 & 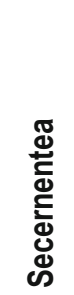 & 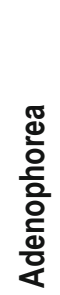 & 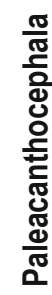 \\
\hline Falconiformes & $85 / 15$ & 3 & 3 & 8 & 0 & 2 \\
\hline Falco cherrug Gray, 1834 & $3 / 2$ & - & - & 2 & - & - \\
\hline Falco columbarius L., 1758 & 1 & - & - & - & - & - \\
\hline Falco peregrinus Tunstall, 1771 & 5 & - & - & - & - & - \\
\hline Falco subbuteo L., 1758 & $3 / 3$ & 1 & - & 3 & - & - \\
\hline Falco tinnunculus L., 1758 & $73 / 10$ & 2 & 3 & 3 & - & 2 \\
\hline Accipitriformes & $156 / 114$ & 63 & 51 & 55 & 19 & 13 \\
\hline Accipiter gentilis L., 1758 & $5 / 3$ & 2 & 1 & 1 & - & - \\
\hline Accipiter nisus L., 1758 & $9 / 5$ & 1 & - & 4 & 1 & - \\
\hline Aquila heliaca Savigny, 1809 & $6 / 4$ & 1 & 2 & 2 & 1 & - \\
\hline Buteo buteo (L., 1758) & $119 / 89$ & 48 & 44 & 41 & 16 & 12 \\
\hline Buteo lagopus (Pontoppidan, 1763) & $5 / 4$ & 2 & - & 4 & 1 & - \\
\hline Buteo rufinus (Cretzschmar, 1829) & $4 / 3$ & 3 & 2 & 2 & - & 1 \\
\hline Circus aeruginosus (L., 1758) & $4 / 3$ & 3 & 1 & 1 & - & - \\
\hline Circus pygargus (L., 1758) & 1 & - & - & - & - & - \\
\hline Haliaeetus albicilla (L., 1758) & $1 / 1$ & 1 & - & - & - & - \\
\hline Milvus milvus (L., 1758) & $1 / 1$ & 1 & - & - & - & - \\
\hline Pernis apivorus (L., 1758) & $1 / 1$ & 1 & 1 & - & - & - \\
\hline Strigiformes & $45 / 28$ & 10 & 6 & 5 & 17 & 19 \\
\hline Asio otus (L., 1758) & $13 / 7$ & 2 & - & - & 6 & 1 \\
\hline Athene noctua (Scopoli, 1769) & 1 & - & - & - & - & - \\
\hline Bubo bubo (L., 1758) & $2 / 2$ & 2 & - & - & 1 & - \\
\hline Glaucidium passerinum (L., 1758) & 1 & - & - & - & - & - \\
\hline Strix aluco L., 1758 & $10 / 3$ & - & 1 & - & 1 & 2 \\
\hline Strix uralensis Pallas, 1771 & $15 / 15$ & 6 & 5 & 5 & 9 & 15 \\
\hline Tyto alba (Scopoli, 1769) & $3 / 1$ & - & - & - & - & 1 \\
\hline
\end{tabular}


Host: B. rufinus ( $\mathrm{NIH}=1 ; \mathrm{P}=25 \%$; $\|=1)$, C. aeruginosus $(\mathrm{NIH}=2$; $\mathrm{P}=50 \% ; \|=1-2 ; \mathrm{Ml}=1.5)$ - first records in Slovakia

Site of infection: small intestine

\section{Strigea falconis Szidat, 1928}

Host: F. tinnunculus $(\mathrm{NIH}=2 ; \mathrm{P}=2.7 \% ; \quad \|=2 ; \mathrm{Ml}=2), A$. gentilis ( $\mathrm{NIH}=2 ; \mathrm{P}=40 \% ; \mathrm{ll}=1-3 ; \mathrm{Ml}=2)$, A. nisus ( $\mathrm{NIH}=1 ; \mathrm{P}=11.1 \% ; \mathrm{ll}=3$ ), A. heliaca (NIH=1; $\mathrm{P}=16.7 \%$; $\|=15), B$. buteo $(\mathrm{NIH}=42 ; \mathrm{P}=35.3 \%$; $\|=1-575 ; M l=35.4)$, B. lagopus ( $\mathrm{NIH}=2 ; \mathrm{P}=40 \% ; \|=5-10 ; \mathrm{Ml}=7.5$ ), B. rufinus $(\mathrm{NIH}=3 ; \mathrm{P}=75 \% ; \quad I=4-18 ; \mathrm{Ml}=10.7)$, C. aeruginosus ( $\mathrm{NIH}=3 ; \mathrm{P}=75 \%$; $\|=1-8 ; \mathrm{Ml}=4)$, M. milvus ( $\mathrm{NIH}=1 ; \mathrm{P}=100 \% ; \|=2$ ) - new host records in Slovakia except for $B$. buteo

Site of infection: small intestine

\section{Strigea strigis Schrank, 1788}

Host: $A$. otus (NIH=2; $\mathrm{P}=15.4 \%$; II=2-4; $\mathrm{Ml}=3)$, B. bubo $(\mathrm{NIH}=1$; $\mathrm{P}=50 \%$; II=2), S. uralensis ( $\mathrm{NIH}=2 ; \mathrm{P}=13.3 \% ; \|=6-17 ; \mathrm{Ml}=11.5)-$ first records in Slovakia

Site of infection: small intestine

\section{Strigea vandenbrokae Dubois, 1936}

Host: $P$. apivorus ( $\mathrm{NIH}=1 ; \mathrm{P}=100 \%$; $\|=7$ ) - first record in Slovakia Site of infection: small intestine

Opisthorchiidae Looss, 1899

Metorchis bilis (Braun, 1790)

Host: $H$. albicilla $(\mathrm{NIH}=1 ; \mathrm{P}=100 \% ; \quad \|=2), B$. rufinus $(\mathrm{NIH}=1$; $\mathrm{P}=25 \%$; II=21) - first records in Slovakia

Site of infection: gall bladder

Plagiorchiidae Lühe, 1901

Plagiorchis elegans (Rudolphi, 1802)

Host: F. subbuteo ( $\mathrm{NIH}=1 ; \mathrm{P}=33.3 \% ; \|=4)$ - new host record in Slovakia

Site of infection: small intestine

Cestoda

Paruterinidae Fuhrmann, 1907

Cladotaenia circi Yamaguti, 1935

Host: C. aeruginosus (NIH=1; $P=25 \%$; $\|=1$ ) - first record in Slovakia

Site of infection: small intestine

\section{Cladotaenia globifera (Batsch, 1786)}

Host: F. tinnunculus (NIH=3; $\mathrm{P}=4,1 \% ; \|=1-2 ; \mathrm{Ml}=1.33), B$. buteo $(\mathrm{NIH}=43 ; \mathrm{P}=36.1 \% ; \|=1-20 ; \mathrm{Ml}=4.4)$, B. rufinus $(\mathrm{NIH}=1 ; \mathrm{P}=25 \%$; $\|=1$ ) - new host records in Slovakia except for $B$. buteo

Site of infection: small intestine

Cladotaenia spasskii Kobyshev, 1971

Host: $A$. heliaca ( $\mathrm{NIH}=2 ; \mathrm{P}=33.3 \%$; $\|=1-4 ; \mathrm{Ml}=2.5)$ - first record in Slovakia
Site of infection: small intestine

Paruterina candelabraria (Goeze, 1782)

Host: S. aluco (NIH=1; $\mathrm{P}=10 \%$; $\|=4)$, S. uralensis $(\mathrm{NIH}=4 ; \mathrm{P}=26.7$ $\% ; \quad I=1-8 ; M l=3.25)$ - first records in Slovakia

Site of infection: small intestine

Dilepididae Railliet et Henry, 1909

Choanotaenia strigium Joyeux \& Timon-David, 1934

Host: S. uralensis ( $\mathrm{NIH}=1 ; \mathrm{P}=6.7 \%$; $\|=4)$ - first record in Slovakia

Site of infection: small intestine

\section{Spiniglans trapezoides (Fuhrmann, 1906) Salamatin, 2000}

Host: $P$. apivorus ( $\mathrm{NIH}=1 ; \mathrm{P}=100 \%$; $\|=1$ ) - first record in Slovakia

Site of infection: small intestine

Mesocestoididae Perrier, 1897

Mesocestoides perlatus (Goeze, 1782)

Host: A. gentilis ( $\mathrm{NIH}=1 ; \mathrm{P}=20 \%$; $\|=1$ ) - first record in Slovakia

Site of infection: small intestine

\section{Mesocestoides sp.}

Host: B. rufinus ( $\mathrm{NIH}=1 ; \mathrm{P}=25 \% ; \|=1)$

Site of infection: small intestine

Anoplocephalidae gen. sp.

Host: $B$. buteo $(\mathrm{NIH}=1 ; \mathrm{P}=0.8 \% ; \|=1)$

Site of infection: small intestine

Nematoda

Secernentea

Syngamidae Leiper, 1912

Cyathostoma americana Chapin, 1925

Host: B. rufinus ( $\mathrm{NIH}=1 ; \mathrm{P}=25 \%$; $\|=2$ ) - first record in Slovakia

Site of infection: trachea

Habronematidae (Chitwood et Wehr, 1932)

Cyrnea leptoptera (Rudolphi, 1819)

Host: F. cherrug $(\mathrm{NIH}=1 ; \mathrm{P}=33.3 \%$; $\|=2)$, F. subbuteo $(\mathrm{NIH}=2$; $\mathrm{P}=66.7 \%$; II=7-18; $\mathrm{Ml}=12,5)$, B. buteo $(\mathrm{NIH}=11 ; \mathrm{P}=9.2 \% ; \|=1-$

$12 ; \mathrm{Ml}=3.55)$, C. aeruginosus ( $\mathrm{NIH}=1 ; \mathrm{P}=25 \% ; \|=1)$, S. uralensis $(\mathrm{NIH}=1 ; \mathrm{P}=6.7 \% ; \|=5)$ - new host records in Slovakia except for B. buteo

Site of infection: gizzard

\section{Cyrnea spinosa (Gendre, 1923)}

Host: F. subbuteo ( $\mathrm{NIH}=1 ; \mathrm{P}=33.3 \%$; $\|=13)$, A. nisus $(\mathrm{NIH}=1$; $\mathrm{P}=11.1 \% ; \|=6)$ - new host records in Slovakia

Site of infection: gizzard

Tetrameridae Travassos, 1914

Microtetrameres cloacitectus Oshmarin, 1956

Host: F. tinnunculus ( $\mathrm{NIH}=2 ; \mathrm{P}=2.7 \% ; \|=4-6 ; \mathrm{Ml}=5), B$. buteo 
$(\mathrm{NIH}=8 ; \mathrm{P}=6.7 \%$ \% $\|=1-183 ; \mathrm{Ml}=32.38)$ - first records in Slovakia Site of infection: gizzard

\section{Microtetrameres oshmarini Sobolev, 1963}

Host: S. uralensis ( $\mathrm{NIH}=3 ; \mathrm{P}=20 \%$; $\|=3-25 ; \mathrm{Ml}=14.67)$ - first record in Slovakia

Site of infection: gizzard

\section{Tetrameres sp.}

Host: S. uralensis ( $\mathrm{NIH}=1 ; \mathrm{P}=6.7 \%$; $\|=1)$ - first record in Slovakia Site of infection: gizzard

Physalopteridae (Railliet, 1893)

Physaloptera alata Rudolphi, 1819

Host: $A$. nisus ( $\mathrm{NIH}=2 ; \mathrm{P}=22.2 \% ; \|=1-7 ; \mathrm{Ml}=4)$ - first record in Slovakia

Site of infection: gizzard

Acuariidae Railliet, Henry et Sisoff, 1912

Synhimantus laticeps (Rudolphi, 1819)

Host: F. tinnunculus (NIH=1; $\mathrm{P}=1.4 \%$; II=2), A. heliaca ( $\mathrm{NIH}=1$; $\mathrm{P}=16.7 \% ; \quad I=3), B$. buteo ( $\mathrm{NIH}=1 ; \mathrm{P}=0.8 \% ; \quad I=2), B$. lagopus $(\mathrm{NIH}=1 ; \mathrm{P}=20 \% ; \|=1), B$. rufinus $(\mathrm{NIH}=1 ; \mathrm{P}=25 \% ; \|=17)$ - first records in Slovakia

Site of infection: oesophagus

Anisakidae Railliet et Henry, 1912

Porrocaecum angusticolle (Molin, 1860)

Host: F. cherrug ( $\mathrm{NIH}=1 ; \mathrm{P}=33.2 \%$; $\|=134)$, A. gentilis $(\mathrm{NIH}=1$; $\mathrm{P}=20 \% ; \|=6)$, A. nisus $(\mathrm{NIH}=1 ; \mathrm{P}=11.1 \% ; \|=3)$, A. heliaca $(\mathrm{NIH}=1$; $\mathrm{P}=16.7 \% ; \|=1)$, B. buteo $(\mathrm{NIH}=24 ; \mathrm{P}=20.2 \% ; \|=1-15 ; \mathrm{Ml}=3.63)$, $B$. lagopus $(\mathrm{NIH}=3 ; \mathrm{P}=60 \% ; \|=1-4 ; \mathrm{Ml}=2.33), B$. rufinus $(\mathrm{NIH}=1$; $P=25 \% ; \|=1)$, S. uralensis ( $N I H=4 ; P=26.7 \% ; \|=1-5 ; M l=2.75)-$ new host records in Slovakia except for $B$. buteo

Site of infection: stomach, small intestine

\section{Porrocaecum depressum (Zeder, 1800)}

Host: $B$. buteo ( $\mathrm{NIH}=8 ; \mathrm{P}=6.7 \%$; $\|=1-49 ; \mathrm{Ml}=9.63)$, B. rufinus $(\mathrm{NIH}=1 ; \mathrm{P}=25 \% ; \|=3)$ - new host record in Slovakia except of B. buteo

Site of infection: stomach, small intestine

\section{Adenophorea}

Capillariidae gen. sp.

Host: $B$. buteo ( $\mathrm{NIH}=10 ; \mathrm{P}=8.4 \% ; \|=1-33 ; \mathrm{Ml}=8.5)$, $B$. lagopus ( $\mathrm{NIH}=1 ; \mathrm{P}=20 \% ; \mathrm{ll}=2)$, A. otus ( $\mathrm{NIH}=5 ; \mathrm{P}=38.5 \% ; \quad l=3-15 ; \mathrm{Ml}=8)$, B. bubo (NIH=1; $\mathrm{P}=50 \%$; $\|=2)$, S. aluco (NIH=1; $P=10 \% ; \|=5), S$. uralensis $(\mathrm{NIH}=4 ; \mathrm{P}=26.7 \% ; \|=2-7 ; \mathrm{Ml}=4.25)$

Site of infection: small intestine

\section{Baruscapillaria falconis (Goeze, 1782)}

Host: A. nisus ( $\mathrm{NHH}=1 ; \mathrm{P}=11.1 \% ; \|=6), A$. heliaca $(\mathrm{NIH}=1$;
$\mathrm{P}=16.7 \% ; \|=3), B$. buteo (NIH=6; $\mathrm{P}=5 \% ; \|=1-14 ; \mathrm{Ml}=6.67), A$. otus $(\mathrm{NIH}=1 ; \mathrm{P}=7.7 \% ; \|=2)$, S. uralensis $(\mathrm{NIH}=5 ; \mathrm{P}=33.3 \% ; \|=4$ 12; $\mathrm{Ml}=8.2)$ - first records in Slovakia

Site of infection: small intestine

\section{Acanthocephala}

Paleacanthocephala

Centrorhynchidae Golvan, 1960

\section{Centrorhynchus aluconis (Muller, 1780)}

Host: $B$. buteo (NIH=1; $\mathrm{P}=0.8 \%$; $\|=5)$, A. otus $(\mathrm{NIH}=1 ; \mathrm{P}=7.7 \%$; $\|=5)$, S. aluco $(\mathrm{NIH}=2 ; \mathrm{P}=20 \% ; \|=5-10 ; \mathrm{Ml}=7.5)$, S. uralensis $(\mathrm{NIH}=15 ; \mathrm{P}=100 \% ; \mathrm{Il}=2-82 ; \mathrm{Ml}=22.4), \mathrm{T}$. alba $(\mathrm{NIH}=1 ; \mathrm{P}=33.3 \%$; $\|=2)$ - new host records in Slovakia except for $B$. buteo and $S$. aluco

Site of infection: small intestine

\section{Centrorhynchus buteonis (Schrank, 1788)}

Host: $B$. buteo $(\mathrm{NIH}=10 ; \mathrm{P}=9.2 \% ; \|=1-15 ; \mathrm{Ml}=6.4)$, B. rufinus $(\mathrm{NIH}=1 ; \mathrm{P}=25 \%$; $\|=39)$ - first records in Slovakia

Site of infection: small intestine

\section{Centrorhynchus globocaudatus (Zeder, 1800)}

Host: F. tinnunculus ( $\mathrm{NIH}=2 ; \mathrm{P}=2.7 \%$; $\|=1-2 ; \mathrm{Ml}=1.5)$, $B$. buteo $(\mathrm{NIH}=1 ; \mathrm{P}=0.8 \% ; \|=3), B$. rufinus $(\mathrm{NIH}=1 ; \mathrm{P}=25 \% ; \|=5)$ - new host records in Slovakia

Site of infection: small intestine

\section{Discussion}

In Europe, there are only few papers comprehensively studying the helminths in birds of prey. The published studies focused mainly on particular groups of birds or certain categories of helminths. Complex surveys involving all three major orders of birds of prey (omitting passeriform shrikes of the Laniidae family) were conducted in the Netherlands (Borgsteede et al., 2003), Spain (Sanmartín et al., 2004; Illescas Gomez et al., 1993), and Italy (Santoro et al., 2012a, b). Ferrer et al. (2004) examined the incidence of helminths only in owls from the territory of Spain. In the Czech Republic, Sitko published decades-long scientific studies of flukes in diurnal (1998) and nocturnal raptors (2001). Research from the territory of Slovakia was published in the former Czechoslovakia by Ryšavý (1957) and Tenora \& Lusk (1960) and comprehensive analyses of flukes and thorny-headed worms were published recently by us (Komorová et al., 2015; Komorová et al., 2016).

Comparisons of the fluke species spectrum in bird orders studied within our research showed certain differences between diurnal (Accipitriformes and Falconiformes) and nocturnal birds of prey (Strigiformes). They are similar to findings of Santoro et al. (2012b) in Calabria (Italy) and Sanmartín et al. (2004) in Galicia (Spain) who observed a relatively narrow range of helminth species within the Strigiformes family, in particular the species specific for owls. This is consistent with our findings in owls with only two detected 
trematode species (Strigea strigis, Neodiplostomum canaliculatum) as was already published by Komorová et al. (2016). Santoro et al. (2012b) found that the helminth fauna of diurnal birds of prey is much more diverse than nocturnal birds. This distinction could be explained by the fact that the ensemble of diurnal bird species includes hosts with different and varied diet spectrum. In consequence, their parasite richness will be the sum of the particular fauna of each bird species (e.g. fish-eating, insectivores, generalist, specialist, etc.) that form the set of hosts. Our results confirmed these findings, since among diurnal birds some flukes, e.g., Conodiplostomum perlatum, Paracoenogonimus ovatus, and Metorchis bilis, were detected exclusively in fish-eating birds of prey species, Strigea vandenbrokae was found only in insectivorous European honey buzzard, and Parastrigea flexilis parasitized members of the Circus genus. On the other hand, the fluke $S$. falconis has a wide host range among Accipitriformes and Falconiformes.

Our results showed that the incidence of flukes was the lowest in the Falconiformes order, where, no species-specific parasites were present (Komorová et al., 2016). Only one species of liver flukes, M. bilis, detected in our material, was confirmed also by a DNA analysis (Sitko et al., 2016).

Similarly, significant differences in the tapeworm species spectrum in nocturnal and diurnal birds of prey have been revealed. While diurnal raptors were hosts of several cestode species, such as Cladotaenia globifera, Cladoteania circi, Cladotaenia spasskii, Spiniglans trapezoides, and Mesocestoides perlatus, owls were parasitized with only two tapeworm species, Paruterina candelabraria and Choanotaenia strigium. Among diurnal raptors, the differences between Falconiformes and Accipitriformes orders were also observed. In Accipitriformes, six cestode species were identified, whereas in Falconiformes C. globifera was the only identified tapeworm. Birds of the Accipitriformes order were infected most frequently and the composition of the tapeworm community was the most diverse. This richness could be caused by the diversity of the order that includes species with different trophic habits. It also can be associated with a considerable variability of this bird order. Among tapeworms, Cladotaenia globifera was the less host-specific species and had the highest prevalence. In contrast, the other tapeworms, e.g., C. circi or C. Spasskii, appeared to be specific to their bird hosts. In older papers from the territory of Slovakia, the synonym Cladotaenia cylindracea was used for the species C. globifera (Ryšavý, 1957; Tenora \& Lusk, 1960). In our material, fragments of cestodes of the Anoplocephalidae family were detected in $B$. buteo. It was probably the only an occasional post-cyclic transmission from infected small vertebrate prey, being the main food component of common buzzards.

Nematodes of the Secernentea class were found in almost all examined species. Parasites of the Cyrnea, Synhimantus and Porrocaecum genera infect a broad spectrum of hosts among diurnal (Falconiformes, Accipitriformes) and also nocturnal (Strigiformes) birds of prey. It was confirmed also by previous findings (Krone,
2000; Borgsteede et al., 2003; Sanmartín et al., 2004; Santoro et al., 2012a, b). Physaloptera alata was the species occurring exclusively in one species of diurnal raptors. As for the Microtetrameres genus, the $M$. cloacitectus species was confirmed in diurnal birds of prey and the M. oshmarini species only in the owls. The finding of a nematode belonging to the Tetrameres genus in Ural owl is remarkable. It requires more thorough examination based on a DNA analysis due to the detection of only a single female individual of this nematode. The Tetrameres genus is quite common in waterfowls (Sitko \& Okulewicz, 2010) but very rare in birds of prey. Ferrer et al. (2004) confirmed Tetrameres sp. in S. aluco in Spain, but the specimen was not determined up to the species level. In Florida, Pence et al. (1975) described the Tetrameres strigiphila species from Strix varia, so the species affiliation of the nematode from Slovakia is highly interesting. The Secernentea class includes epidemiologically important species and can be considered as the most pathogenic helminth group in birds of prey. In particular, intense infections with species of the Porrocaecum genus identified in the widest range of hosts represent a serious impact on the health of the birds. It was, for instance, demonstrated by the death of a saker falcon infected with a large number of Porrocaecum angusticolle nematodes.

Regarding the nematode class of Adenophorea, the Capillariidae family was represented most often. These findings were quite common and involved a wide range of hosts. However, the species determination was not possible in most cases due to the bad conservation of materials, except for few specimens that could be identified, such as Baruscapillaria falconis.

Our results on the species spectrum of acanthocephalans (Paleacanthocephala) in the three orders of birds of prey revealed the exclusive presence of Centrorhynchus aluconis in Strigiformes, Centrorhynchus buteonis in Falconiformes, and C. buteonis, or $C$. buteonis. Centrorhynchus globocaudatus co-infections were most frequently found in Accipitriformes (Komorová et al., 2015, and this paper). The presence of $C$. aluconis in diurnal birds of prey was demonstrated in one case but the parasite reproduction in the host was not confirmed.

Marked differences in helminth communities between the owls and the diurnal raptors (Accipitriformes and Falconiformes) have been reported by Santoro et al. (2012b) in southern Italy. The majority of literature data on acanthocephalans of birds of prey suggests a rather low host specificity of individual species of the Centrorhynchus genus. For instance, $C$. aluconis is considered as an owl parasite in Europe (Kutzer et al., 1982; Kritscher 1985; Ewald \& Crompton, 1993; Mclnnes et al., 1994; Sitko 1994; Dimitrova et al., 1995; Ferrer et al. 2004; Dimitrova \& Dimitrova 2012; Santoro et al., 2012b; Lisitsyna \& Greben, 2015), but it has sometimes been observed also in diurnal raptors (Yamaguti 1963, Illescas Gomez et al. 1993; Borgsteede et al. 2003, Sitko 2011). On the other hand, C. buteonis has been documented not only in Falconiformes and Accipitriformes, but also in owls, especially in the Strix genus (Furmaga, 1957; Yamaguti, 1963; Michálek, 1984; Kritscher, 1985; 
Sitko 2011; Dimitrova \& Dimitrova, 2012; Shirazi et al., 2014). The widest host range, as confirmed by the above mentioned authors, was observed in C. globocaudatus, primarily infecting diurnal raptors (Sanmartín et al., 2004; Lisitsyna \& Greben, 2015).

Within our research, a total of 23 helminth species consisting of ten Trematoda species, six Cestoda species, five taxa of the Secernentea class, and one species of Paleacanthocephala were observed for the first time in birds of prey from Slovakia. Regarding the helminths previously found in Slovakia, lots of new hosts were listed. The total number of new host observations is 31 . Most of them were confirmed for the $S$. falconis fluke which was detected in eight new avian species.

\section{Acknowledgement}

The study was supported by the project "Centre of Excellence for Parasitology" (ITMS Code: 26220120022) based on the support of the Operational Programme "Research \& Development" funded from the European Regional Development Fund $(1,0)$.

\section{References}

Baruš, V., Sergeeva, T.P., Sonin, M.D., Ryzhikov, K.M. (1978): Helminths of Fish-Eating Birds of the Palearctic Region I. Academia Praha, 318 pp. DOI: 10.1007/978-94-009-9972-5

Borgsteede, F.H.M., Okulewicz, A., Zoun, P.E.F., Okulewicz, J. (2003): The helminth fauna of birds of prey (Accipitriformes, Falconiformes and Strigiformes) in the Nederlands. Acta Parasitol., 48: $200-207$

Bray, R.A., GiBSon, D.I., Jones, A. (2008): Keys to the Trematoda. Volume 3. CAB International and The Natural History Museum, London, $805 \mathrm{pp}$.

Bush, A.O., LAfFerty, K.D., Lotz, J.M., Shostak, A.W. (1997): Parasitology meets ecology on its own terms: Mangolis et al., revisited. J. Parasitol., 83: 4, 575 - 583. DOI: 10.7939/R3J38KV04

Dimitrova, Z. M., Dimitrova, N. (2012): Review of species of the phylum Acanthocephala from the Middle-Bulgarian Region. Agric. Sci. Technol. Stara Zagora, 4: 159 - 165

Dimitrova, Z.M., GiBSON, D.I. (2005): Some species of Centrorhynchus Luhe, 1911 (Acanthocephala: Centrorhynchidae) from the collection of the Natural History Museum, London. Syst. Parasitol., 62: 117 - 134. DOI: 10.1007/s11230-005-5486-7

Dimitrova, Z.M., Georgiev, B.B., Genov, T. (1997): Acanthocephalans of the family Centrorhynchidae (Paleacanthocephala) from Bulgaria. Folia Parasitol., 44: 224 - 232

Dimitrova, Z.M., Mural, E., Genov, T. (1995): Some species of the family Centrorhynchidae Van Cleave, 1916 (Acanthocephala) from Hungarian birds. Parasit. Hung., 28: 89 - 99

DuBols, G. (1968): Synopsis des Strigeidae et des Diplostomatidae (Trematoda). I. Strigeidae [Synopsis of the Strigeidae and of the Diplostomatidae (Trematoda). I. Strigeidae]. Mem. Soc. Sci. Nat. Neuchatel, 10: 1 - 258
DuBols, G. (1970): Synopsis des Strigeidae et des Diplostomatidae (Trematoda). II. Diplostomatidae [Synopsis of the Strigeidae and of the Diplostomatidae (Trematoda) II. Diplostomatidae]. Mem. Soc. Sci. Nat. Neuchatel, 10: $259-727$

Ewald, J.A., Crompton, D.W.T. (1993): Centrorhynchus aluconis (Acanthocephala) and other helminth species in tawny owls (Strix aluco) in Great Britain. J. Parasitol., 79: 952 - 954

Ferrer, D., Molina, R., Castella, J., Kinsella, J.M. (2004): Parasitic helminths in the digestive tract of six species of owls (Strigiformes) in Spain. Vet. J., 167: 181 - 185. DOI: 10.1016/S10900233(03)00103-5

FuRMAGA, S. (1957): The helminth fauna of predatory birds (Accipitres and Striges) of the environment of Lublin. Acta Parasitol., 5: $215-287$

Georgiev, B.B., Biserkov, V., Genov, T. (1986): In toto staining method for cestodes with iron acetocarmine. Helminthologia, 23: $279-281$

GibBons, L.M. (2010): Keys to the Nematode Parasites of Vertebrates. Suplementary volume. CAB International, Wallingford (UK), 416 pp.

Gibson, D.I., Jones, A., Bray, R.A. (2002): Keys to the Trematoda. Volume 1. CAB International and The Natural History Museum, London, $521 \mathrm{pp}$.

Hartwich, G. (1975): Rhabditida und Ascaridida. Die Tierwelt Deutschlands. 62 Teil. Gustav Fischer Verlag, Jena, 256 pp.

Illescas Gomez, M.P., Rodriguez Osorio, M., Aranda Maza, F. (1993): Parasitation of Falconiform, Strigiform and Passeriform (Corvidae) birds by helminths in Spain. Res. Rev. Parasitol., 53: $129-135$

Joyeux, Ch., Baer, J. G. (1936): Faune de France 30. Cestodes [Fauna of France 30. Cestoda]. Typographie Firmin-Didot, 613 pp. Joyeux, Ch., Timon-David, J. (1934): Note sur des Cestodes D'Oiseaux. Récoltés dans la région de Marseille [Note on Cestodes of Birds. Collected in the region of Marseille]. Annales du Musée D'Histoire Naturelle de Marseille, Tome XXVI. - Mémoire VI., 5-8 KHALIL, L.F., Jones, A., Bray, R.A. (1994): Keys to the cestode parasites of vertebrates. St Albans, CAB International, $751 \mathrm{pp}$.

Komorová, P., Špakulová, M., HurníKovÁ, Z., Uhrín, M. (2015): Acanthocephalans of the genus Centrorhynchus (Paleacanthocephala: Centrorhynchidae) of birds of prey (Falconiformes) and owls (Strigiformes) in Slovakia. Parasitol. Res., 114(6): 2273 - 2278. DOI: 10.1007/s00436-015-4420-4

Komorová, P., Sitko, J., Špakulová, M., Hurníková, Z. (2016): Intestinal and liver flukes of birds of prey (Accipitriformes, Falconiformes, Strigiformes) from Slovakia: uniform of diverse compound? Parasitol. Res., 115(7): 2837 - 2844. DOI: 10.1007/s00436-016-5034-1 Kovalik, P., Topercer, J., Karaska, D., Danko, Š., Šrank, V. (2010): Zoznam vtákov Slovenska k 7. 4. 2010 [The list of birds of Slovakia as to 7.4.2010]. Tichodroma, 22: 97 - 10 (In Slovak)

KRITSCHER, E. (1985): Catalogus faunae Austriae: Aschelminthes, Schlauchwürmer; Nemertini, Schnurwürmer. Teil 4. Phylum: Acanthocephala. Verl. Österr. Akad. Wiss. Wien, 4: 1 - 15 
KRIVJANSKÝ, T. (2009): Sokoliarstvo - 2. diel: Naše dravce a sovy [Falconry - part 2: Our raptors and owls]. Vydavatel'stvo EPOS, 336 pp. (In Slovak)

KRONE, O. (2000). Endoparasites of free-ranging birds of prey in Germany. In: LumeiJ, J.T., Remple, J.D., Reding, P.T., Lierz, M., COOPER, J.E. (Eds) Raptor Biomedicine III. Zoological Educational Network, pp. $101-116$

Kutzer, E., FreY, H., Nöbauer H. (1982): Zur parasitenfauna österreichischer eulenvögel (Strigiformes) [Parasite fauna of Austrian owls (Strigiformes)]. Angew. Parasitol., 23:190 - 197 (In German) Lisitsyna, O.I., Greben, O.B. (2015): Acanthocephalans of the genus Centrorhynchus (Paleacanthocephala, Centrorhynchidae) from birds of Ukraine with the description of a new species. Vestn. Zool., 49(3):195 - 210

Mclnnes, F.J., CRompton, D.W.T., Ewald, J.A. (1994): The distribution of Centrorhynchus aluconis (Acanthocephala) and Porrocaecum spirale (Nematoda) in Tawny Owls (Strix aluco) from Great Britain. J. Raptor Res., 28(1):34 - 38

Meyer, A. (1933): Acanthocephala. Vierter Band, 2. Abt. 2. Buch, Leipzig: Academische Verlagsgesellshaft M.B.H., 582 pp.

MıCHÁLEK, J. (1984): Record of Physaloptera alata Rudolphi, 1819 and Centrorhynchus buteonis (Schrank, 1788) in Falconiformes in Czechoslovakia. Folia Parasitol., 31: 383 - 384

Pence, D.B., Mollhagen, T., Forrester, D.J. (1975): Tetrameres (Gynaecophila) strigiphila sp. n. from the Florida Barred Owl, Strix varia georgica, with Notes on the Status of the Subgenus Gynaecophila (Nematoda: Tetrameridae). J. Parasitol., 61: 494 - 498

Petrochenko, V.I. (1958): Acanthocephala of domestic and wild animals. Vol. II. Moscow, Izdat. AN SSSR, 458 pp.

RAUSH, R.L. (1948): Observations on cestodes in North America owls with the description of Choanotaenia speotytonis $n$. sp. (Cestoda: Dipylidiinae). Faculty Publications from the Harold W. Manter Laboratory of Parasitology, 462 - 471

RYŠAVÝ, B. (1957): Zur Kenntnis der Helminthenfauna der Vögel in der Tsechoslowakei [To the knowledge of the helminthfauna of the birds in Czechoslovakia]. Českoslov. parasit., 4: 299 - 329 (In German)

Sanmartín, M.L., Álvarez, F., Barreiro, G., Leiro, J. (2004): Helminth fauna of Falconiform and Strigiform birds of prey in Galicia, Northwest Spain. Parasitol. Res., 92: 255 - 263. DOI: 10.1007/ s00436-003-1042-z
Santoro, M., Kinsella, J.M., Galiero, G., Degli Uberti, B., Aznar, F.J. (2012a): Helminth community structure in birds of prey (Accipitriformes and Falconiformes) in Southern Italy. J. Parasitol., 98(1): 22 - 29. DOI: 10.1645/GE-2924.1

Santoro, M., Mattiucci, S., Nascetti, G., Kinsella, J.M., Di Prisco, F., Sabatino, T., D'Alessio, N., Veneziano, V., Aznar, F.J. (2012b): Helminth communities of owls (Strigiformes) indicate strong biological and ecological differences from birds of prey (Accipitriformes and Falconiformes) in Southern Italy. PIOS ONE, 7(12), e53375. DOI: 10.1371/journal.pone.0053375

Shirazi, S., Hesaraki, S., Mostafael, T.S., Davoodi, J. (2014): First report on Centrorhynhus aluconis in common buzzard (Buteo buteo) in Northwest Iran. Acta Vet. (Beogr.), 64: 276 - 280. DOI: 10.2478/acve-2014-0026

SITKO, J. (1994): Helminths of birds of prey (Falconiformes) and owls (Strigiformes) in Czech Republic and their influence on health condition of caged birds. Zpr. morav. ornitol. stan., 52: 53 - 84

SitKo, J. (1998): Trematodes of birds of prey of Czech Republic. Helminthologia, 32: 131 - 146

SiTKo, J. (2001): Trematodes of owls (Aves: Strigiformes) in the Czech Republic. Acta Soc. Zool. Bohem., 65: 45 - 56.

SitKo, J. (2011): Checklist of the Acanthocephala in birds in the Czech Republic and the Slovak Republic. Comenius Museum Přerov, $35 \mathrm{pp}$.

SitKo, J., OKULEWICZ, A. (2010): Checklist of the Nematodes of birds of the Czech Republic and the Slovak Republic. Comenius Museum Přerov, $100 \mathrm{pp}$.

Sitko, J., Bizos, J., Sherrard-Smith, E., Stanton, D.W.G., KomorovÁ, P., Heneberg, P. (2016): Integrative taxonomy of European parasitic flatworms of the genus Metorchis Looss, 1899 (Trematoda: Opisthorchiidae). Parasitol. Int., 65: 258 - 267. DOI: 10.1016/j. parint.2016.01.011

ŠKARDA, J. (1964): The helminthfauna of some wild birds in Czechoslovakia. Acta Univ. Agric. Brno B, 12: 269 - 293

TENORA, F., Lusk, S. (1960): Beitrag zur näheren Kenntnis der Helminthenfauna bei Raubvögeln (Falconiformes) in der Tschechoslowakei [Contribution to the closer knowledge of the helminthfauna in birds of prey (Falconiformes) in Czechoslovakia]. Acta Univ. Agric. Brno A, 2: 205 - 211 (In German)

Yamaguti, S. (1963): Acanthocephala. Vol. V, Systema Helminthum. Interscience, New York, 423 pp. 